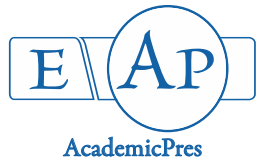

\title{
Growth, Yield and Proximate Composition of Aromatic Rice as Influenced by Inorganic and Organic Fertilizer Management
}

\author{
Md. Jafrul Islam SUMON ${ }^{1}$, Tuhin Suvra ROY ${ }^{1}$, Md. Nazmul HAQUE ${ }^{1 *}$, \\ Salma AHMED ${ }^{2}$, Kanika MONDAL ${ }^{2}$
}

${ }^{1}$ Sher-e-Bangla Agricultural University, Faculty of Agriculture, Department of Agronomy, Dhaka 1207,

Bangladesh; sumon2539@gmail.com (*corresponding author)

${ }^{2}$ Applied Nutrition Research Section, Institute of Food Science and Technology, Bangladesh Council of Scientific and

Industrial Research (BCSIR), Dhaka-1205, Bangladesh

\begin{abstract}
Integrated use of organic and inorganic fertilizers can improve crop productivity and sustain soil health and fertility. To gain insights into the response of green manure and chemical fertilizer, the present study was conducted to evaluate the growth, yield and proximate composition of aromatic rice varieties in Aman season at the research farm of Sher-e-Bangla Agricultural University, Dhaka, Bangladesh during the period from July to December 2014. The experiment was set up in split-plot design with three aromatic rice varieties in main plots and six fertilizer levels in subplots. 'Raniselute' variety produced the highest plant height, dry matter weight hill' ${ }^{-1}$, straw yield $\left(7.81 \mathrm{t} \mathrm{ha}^{-1}\right)$, biological yield $\left(9.05 \mathrm{t} \mathrm{ha}^{-1}\right)$, ash (1.59\%), and fat content (2.81\%). 'BRRI dhan34' gave the maximum number of effective tillers hill-1 $(12.74)$, panicle length $(27.93 \mathrm{~cm})$, number of filled grains panicle-1 (192.5), 1,000-grain weight (17.22 g), grain yield (2.26 $\left.\mathrm{t} \mathrm{ha}^{-1}\right)$, harvest index (29.99\%), and carbohydrate content $(77.63 \%)$. Application of $80 \%$ recommended doses of NPKSZn + green manure $3.5 \mathrm{t} \mathrm{ha}^{-1}$ showed better performance for getting the maximum growth, yield components and yield compared to other treatments. Recommended doses of NPKSZn showed the highest carbohydrate content (77.63\%) and lowest moisture (8.75\%) and ash content (1.29\%). The maximum fat content (3.07\%) and minimum carbohydrate content (76.53\%) was obtained from $60 \%$ recommended doses of NPKSZn + green manure $7 \mathrm{t} \mathrm{ha}^{-1}$. Application of 20 and $40 \%$ recommended doses of NPKSZn + green manure 14 and $10.5 \mathrm{t} \mathrm{ha}^{-1}$ produced the highest moisture content (10.43\%) and lowest protein content (8.26\%) in rice grain. Green manure $17.5 \mathrm{t} \mathrm{ha}^{-1}$ produced the highest ash (1.79\%), protein content (9.06\%) and lowest fat content (2.51\%).
\end{abstract}

Keywords: fine rice; Integrated Nutrient Management; Oryza sativa L.; proximate composition; transplant Aman; 2-Acetyl-1pyrroline

\section{Introduction}

Rice (Oryza sativa L.) is one of the major food crops grown in South Asia. It is mostly grown in lowlands under fully irrigated or rain-fed conditions. The people in Bangladesh depend on rice as staple food and have a tremendous influence on the agrarian economy of Bangladesh. Rice alone constitutes $97 \%$ of the food grain production in Bangladesh (BBS, 2013). Among different groups of rice, transplant Aman (T. Aman) rice cover about $49.11 \%$ of total rice area, and it contributes to $38.11 \%$ of the total rice production in the country (BBS, 2013). In Bangladesh, rice dominates over all other crops and covers $75 \%$ of the total cropped area (Rekabdar, 2004) of which around $27 \%$ is occupied by fine rice varieties (BBS, 2003). Although the nutritional values of rice vary with different varieties, soil fertility, fertilizer application and other environmental conditions, the following trend still exists by comparison with other cereals: low-fat content after the removal of the bran, low protein content (about 7-10\%), and higher digestibility of protein. Rice is considered as the queen among cereals due to its nutritional quality and higher digestibility (Anjum et al., 2007). Freshly harvested rice grains contain about $80 \%$ carbohydrate which includes starch, glucose, sucrose, and dextrin (Verma and Srivastav, 2017).

Rice can be classified as aromatic and non-aromatic rice by aroma. Aromatic rice emits a unique aroma with cooking. Indian sub-continent is a habitat for aromatic rice 
212

diversity (Bisne and Sarawgi, 2008). In aromatic rice, the flavor is expended as one of the most significant factors in market business, which distinguishes aromatic rice from ordinary rice (Laohakunjit and Kerdchoechuen, 2007; Fitzgerald et al., 2009). This flavor compound is stemming primarily from its 2-Acetyl-1-pyrroline content (Bhattacharjee et al., 2002), which generally plays a role in consumer acceptability of rice (Bergman et al., 2000). Consumers have become more quality conscious about the rice cultivars they consume. Therefore, it needs to be focused on the quality of rice along with production. When farmers become conscious of their rice quality, they were driven to produce better quality rice (Dela Cruz and Khush, 2000; Yoshihashi et al., 2004). Nowadays, scientists and breeders are more and more focused on improving the quality of rice for different purposes and markets. For instance, consumers from developed countries ask mainly for grain with good cooking quality and eating characteristics, but in many developing regions, nutritional value is crucial as rice is the most consumed staple food. Grain quality is a general concept which covers many characteristics ranging from physical to biochemical and physiological properties. The traits and parameters used to evaluate grain quality in rice vary across countries. However, four main quality traits (Yu et al., 2008) are widely used to assess quality, namely milling properties, appearance, nutritional value, and cooking quality. Besides that, grain quality has been shown to be affected significantly by growing and environmental conditions, such as water availability, temperature, fertilizer application, drought, and salinity stresses (Chen et al., 2012).

Rice farmers have traditionally used organic materials particularly farmyard manure and green manures in the preindustrial age. Green manuring can improve soil physical, chemical, and biological properties and consequently crop yields (Fageria, 2007). Importance of this soil ameliorating practice is increasing in recent years because of increasing prices and low efficiency of chemical $\mathrm{N}$ fertilizer and low organic matter content of our soils, inclusion of green manuring crops in the rice-based cropping systems, deserves priority consideration (Bhuiyan and Zaman, 1996). But with the present day high yielding cultivars, which have higher nutrient requirements, the use of inorganic fertilizers has increased considerably leading to declining in the use of organic materials (Hossain and Singh, 2000). It is well known that sustainable production of crops cannot be maintained by using only chemical fertilizers and similarly it is not possible to obtain higher crop yield by using organic manure alone (Bair, 1990). For sustainable agriculture and to ensure the food production with high quality it is necessary to combined use of organic and inorganic sources of nutrients (Mahmud et al., 2016).

Though rice is one of the most vital crops of the world but enough information regarding the varieties of fine rice and their response to green manure and chemical fertilizers are scarce in the world literature. In view of limited information on the problems mentioned above, this present study was therefore, undertaken to compare the growth, yield and quality performance of three aromatic Aman rice varieties using the different combination of green manure and chemical fertilizers.

\section{Materials and Methods}

\section{Experimental location and climate}

The study was carried out at Sher-e-Bangla Agricultural University, Dhaka, Bangladesh situated at $23^{\circ} 46^{\prime} \mathrm{N}$ latitude and $90^{\circ} 23^{\prime}$ E longitude at an altitude of $8.45 \mathrm{~m}$ above the sea level during the period from July to December 2014. The experimental site is under sub-tropical humid climatic conditions with a total annual rainfall was $24.23 \mathrm{~mm}$ with average monthly maximum and minimum temperature of $29.64^{\circ} \mathrm{C}$ and $14.91^{\circ} \mathrm{C}$, respectively. The soil of the experimental soil was silty clay in texture under Tejgaon series with sand $(26 \%)$, silt $(45 \%)$, clay $(29 \%)$, soil $\mathrm{pH}$ (5.60), organic carbon $(0.45 \%)$, organic matter $(0.78 \%)$, total $\mathrm{N}(0.03 \%)$, available $\mathrm{P}$ (20.54 $\mathrm{mg} \mathrm{kg}^{-1}$ soil) and exchangeable K $(0.10 \mathrm{meq} / 100 \mathrm{~g}$ soil $)$.

\section{Planting material}

Rice cvs. 'Kataribhog', 'Raniselute' and 'BRRI dhan34' were used as a test crop. These varieties are recommended for Aman season. All the variety had photo-sensitivity and well known for their characteristic aroma.

\section{Raising and transplanting of seedling}

The seedlings of rice were raised in the wet bed methods. Hand spade was used to open the selected seed-bed on $11^{\text {th }}$ June 2014. Initially seed soaking was done in water for 24 hours, and afterwards, they were kept tightly in jute sack for 3 days. When about $90 \%$ of the seeds were sprouted, they were sown uniformly in well prepared wet nursery bed on $5^{\text {th }}$ July 2014. Seed-bed size was $10 \mathrm{~m}$ long and $1.5 \mathrm{~m}$ wide. 25 days old seedlings were carefully uprooted from the seedling nursery and transplanted on $1^{\text {st }}$ August 2014. Two seedlings per hill were used following a line to line of $20 \mathrm{~cm}$ and hill to hill spacing of $15 \mathrm{~cm}$. After one week of transplantation, all plots were checked for any missing hill which was filled in with extra seedlings whenever required.

\section{Land preparation}

First, the land was ploughed with a power tiller at 15 days before transplanting. The soil was saturated with an adequate supply of irrigation water and finally prepared by successive ploughing and cross ploughing followed by laddering. The unexpected residues were removed from the experimental plot. Finally, the land was levelled and the experimental plot was partitioned into unit plots by experimental design.

\section{Experimental treatments and design}

The experiment consisted of two factors i.e., 3 varieties of aromatic rice viz., $\mathrm{V}_{1}=$ Kataribhog, $\mathrm{V}_{2}=$ Raniselute, $\mathrm{V}_{3}=$ BRRI dhan34 and 6 levels of fertilizer management viz., $\mathrm{T}_{1}$ $=$ Recommended doses of NPKSZn, $\mathrm{T}_{2}=80 \%$ recommended doses of NPKSZn + green manure $3.5 \mathrm{t} \mathrm{ha}^{-1}$, $\mathrm{T}_{3}=60 \%$ recommended doses of NPKSZn + Green Manure $7 \mathrm{tha}^{-1}, \mathrm{~T}_{4}=40 \%$ recommended doses of NPKSZn + green manure $10.5 \mathrm{t} \mathrm{ha}^{-1}, \mathrm{~T}_{5}=20 \%$ recommended doses of NPKSZn + green manure $14 \mathrm{tha}^{-1}, \mathrm{~T}_{6}=$ Green manure $17.5 \mathrm{t} \mathrm{ha}^{-1}$. The two factors experiment was arranged in a split-plot design with three replications. The three varieties were assigned in the main plot and six levels of fertilizer 
management treatments in sub-plot. The size of each unit plot was $3 \mathrm{~m} \times 2 \mathrm{~m}\left(6 \mathrm{~m}^{2}\right)$. The space between two blocks and two plots were $1.0 \mathrm{~m}$ and $0.5 \mathrm{~m}$, respectively.

\section{Green manure and fertilizer application}

The green manures (dhaincha) are uprooted before flowering and chopped into small parts and then directly incorporated into the soil of the field before transplanting. The field was fertilized with nitrogen, phosphate, potash, sulfur and zinc at the rate of 120, 100, 70, 60 and $10 \mathrm{~kg} \mathrm{ha}^{-1}$, respectively in the form of urea, triple super-phosphate, muriate of potash, gypsum and zinc sulfate. The whole amount of all the fertilizers except urea were applied at the time of final land preparation and thoroughly incorporated with soil with the help of a spade. Urea was top dressed in three equal splits on 15,30, and 45 DAT.

\section{Harvesting}

The maturity of crop was determined when $85 \%$ to $90 \%$ of the grains become golden yellow in color. BRRI dhan 34 and Kataribhog varieties were harvested at $15^{\text {th }}$ November 2014 and Raniselute at $29^{\text {th }}$ November 2014. From the centre of each plot $1 \mathrm{~m}^{2}$ area was harvested to determine yield of individual treatment and converted into $\mathrm{tha}^{-1}$. The harvested crop of each plot was bundled separately and tagged properly.

\section{Biological yield ( $t$ ha ${ }^{-1}$ )}

The biological yield was calculated by using the following formula:

Biological yield $=$ Grain yield + Straw yield

\section{Harvest index (\%)}

The harvest index is the relationship between grain yield and biological yield (Gardner et al., 1985). It was calculated by using the following formula:

$$
\mathrm{HI}(\%)=\frac{\text { Grain yield }}{\text { Biological yield }} \times 100
$$

\section{Moisture content of rice seed (\%)}

The moisture content was calculated by using the following formula:

Moisture $(\%)=$ Sample weight-Constant dry weight of sample Sample weight

\section{Ash content of rice seed (\%)}

The ash content of rice seed was determined by following AOAC method (AOAC, 1975).

\section{Fat content of rice seed (\%)}

The fat content of rice seed was determined by the Soxhlet Oxidation procedure (AOAC, 1975) using $10 \mathrm{~g}$ of samples and petroleum ether extraction is done continuously for 8 hours.

\section{Protein content of rice seed (\%)}

The protein content of rice seed was determined by the Micro-Kjeldahl method using automated nitrogen determination system (AOAC, 1990).
Carbohydrate content of rice seed (\%)

The carbohydrate content of rice seed was determined by following AOAC method (AOAC, 1990).

\section{Statistical analysis}

The data were subjected to analysis of variance (ANOVA), and the mean differences were compared by Least Significant Difference (LSD) test using MSTAT-C (Gomez and Gomez, 1984). Differences at $P \leq 0.05$ were considered significant.

\section{Results and Discussion}

\section{Growth contributing characters \\ Plant height}

Aman rice variety exhibited significant difference in plant height at different growth stages except for 90 DAT (Table 1). Among the varieties, Raniselute significantly showed the tallest plant and the shortest plant was found in BRRI dhan34. Plant height is dependent on the number of internodes and their length. It represents the varietal characteristics of a variety. The differences in plant height of different varieties might have resulted from the genetic makeup of the cultivars, but the environmental factors also influence a little. The results were in agreement with Bisne et al. (2006); Islam et al. (2013); Roy et al. (2014) who observed plant height differed significantly among the varieties.

Effect of green manure and chemical fertilizer showed a significant variation on plant height for all growth stages (Table 1). The tallest plant was recorded from $80 \%$ recommended doses of NPKSZn + green manure $3.5 \mathrm{t} \mathrm{ha}^{-1}$ which was statistically similar with recommended doses of NPKSZn and 60\% recommended doses of NPKSZn + green manure $7 \mathrm{tha}^{-1}$, while the shortest plant was recorded from green manure $17.5 \mathrm{t} \mathrm{ha}^{-1}$ which was statistically similar with $20 \%$ recommended doses of NPKSZn + green manure $14 \mathrm{t} \mathrm{ha}^{-1}$ except $15 \mathrm{DAT}$. The increase in plant height due to the application of $80 \%$ recommended doses of NPKSZn + green manure $3.5 \mathrm{t} \mathrm{ha}^{-1}$ might be associated with stimulating effect on various physiological processes including cell division and cell elongation of the plant. These results are agreed with that of Kohayashi et al. (1989) who observed increasing plant height with FYM + fertilizer $\mathrm{N}$ applied plots.

\section{Dry matter content bill $^{-1}$}

Significant variation was observed on dry matter content hill $^{-1}$ at different growth stages of Aman rice variety except for 15 DAT (Table 2). Among the varieties, Raniselute showed the maximum and BRRI dhan34 gave the minimum dry matter content hill ${ }^{-1}$.

Effect of green manure and chemical fertilizer showed a significant variation on dry matter weight hill ${ }^{-1}$ for all growth stages (Table 2 ). The maximum dry matter weight hill $^{-1}$ was recorded in $80 \%$ recommended doses of NPKSZn along with green manure $3.5 \mathrm{t} \mathrm{ha}^{-1}$ which was statistically similar with recommended doses of NPKSZn, while the minimum was recorded in green manure $17.5 \mathrm{t} \mathrm{ha}^{-1}$. 
Table 1. Effect of varietal variation and fertilizer management on plant height of rice at different days after transplanting (DAT)

\begin{tabular}{|c|c|c|c|c|c|c|c|}
\hline \multirow{2}{*}{ Variety } & \multicolumn{7}{|c|}{ Plant height $(\mathrm{cm})$ at } \\
\hline & $15 \mathrm{DAT}$ & $30 \mathrm{DAT}$ & $45 \mathrm{DAT}$ & $60 \mathrm{DAT}$ & $75 \mathrm{DAT}$ & $90 \mathrm{DAT}$ & Harvest \\
\hline $\mathrm{V}_{1}$ & $45.50 \mathrm{~b}$ & $72.50 \mathrm{~b}$ & $106.6 \mathrm{~b}$ & $116.2 \mathrm{~b}$ & $126.0 \mathrm{~b}$ & 134.5 & $143.2 \mathrm{ab}$ \\
\hline $\mathrm{V}_{2}$ & $59.05 \mathrm{a}$ & $95.72 \mathrm{a}$ & $122.2 \mathrm{a}$ & $127.0 \mathrm{a}$ & $134.6 \mathrm{a}$ & 142.3 & $148.1 \mathrm{a}$ \\
\hline $\mathrm{V}_{3}$ & $43.02 \mathrm{~b}$ & $71.70 \mathrm{~b}$ & $105.4 \mathrm{~b}$ & $110.7 \mathrm{~b}$ & $120.7 \mathrm{c}$ & 132.2 & $139.7 \mathrm{~b}$ \\
\hline $\operatorname{LSD}_{(0.05)}$ & 5.332 & 3.257 & 4.533 & 7.737 & 4.249 & ns & 7.172 \\
\hline \multicolumn{8}{|c|}{ Fertilizer management } \\
\hline $\mathrm{T}_{1}$ & $48.21 \mathrm{~b}$ & $83.52 \mathrm{ab}$ & $115.4 \mathrm{ab}$ & $123.2 \mathrm{a}$ & $131.1 \mathrm{a}$ & $142.4 \mathrm{a}$ & $147.4 \mathrm{a}$ \\
\hline $\mathrm{T}_{2}$ & $48.42 \mathrm{~b}$ & $86.04 \mathrm{a}$ & $117.3 \mathrm{a}$ & $122.5 \mathrm{a}$ & $132.1 \mathrm{a}$ & $142.0 \mathrm{a}$ & $148.7 \mathrm{a}$ \\
\hline $\mathrm{T}_{3}$ & $50.92 \mathrm{ab}$ & $80.48 a-c$ & $112.6 \mathrm{a}-\mathrm{c}$ & $121.0 \mathrm{a}$ & $129.9 \mathrm{ab}$ & $137.5 \mathrm{ab}$ & $144.3 \mathrm{ab}$ \\
\hline $\mathrm{T}_{4}$ & $47.22 \mathrm{~b}$ & $78.00 \mathrm{bc}$ & $110.4 \mathrm{~b}-\mathrm{d}$ & $117.4 \mathrm{ab}$ & $126.3 \mathrm{bc}$ & $135.2 \mathrm{ab}$ & $142.2 \mathrm{ab}$ \\
\hline $\mathrm{T}_{5}$ & $47.53 \mathrm{~b}$ & $77.45 \mathrm{bc}$ & $107.7 \mathrm{~cd}$ & $113.0 \mathrm{~b}$ & $122.4 \mathrm{~cd}$ & $132.3 \mathrm{ab}$ & $142.1 \mathrm{ab}$ \\
\hline $\mathrm{T}_{6}$ & $52.85 \mathrm{a}$ & $74.37 \mathrm{c}$ & $105.0 \mathrm{~d}$ & $110.8 \mathrm{~b}$ & $120.9 \mathrm{~d}$ & $128.6 \mathrm{~b}$ & $137.6 \mathrm{~b}$ \\
\hline $\operatorname{LSD}_{(0.05)}$ & 3.858 & 7.355 & 5.649 & 6.921 & 3.991 & 12.51 & 8.380 \\
\hline
\end{tabular}

Figures not sharing the same letters differ significantly at $P \leq 0.05$

$V_{1}$ : Kataribhog, V2: Raniselute, V3: BRRI dhan34

$\mathrm{T}_{1}=$ Recommended doses of NPKSZn, $\mathrm{T}_{2}=80 \%$ recommended doses of NPKSZn + green manure $3.5 \mathrm{tha} \mathrm{h}^{-1}, \mathrm{~T}_{3}=60 \%$ recommended doses of NPKSZn + green manure $7 \mathrm{t} \mathrm{ha}^{-1}, \mathrm{~T}_{4}=40 \%$ recommended doses of NPKSZn + green manure $10.5 \mathrm{t} \mathrm{ha}^{-1}, \mathrm{~T}_{5}=20 \%$ recommended doses of NPKSZn + green manure $14 \mathrm{t}$ ha ${ }^{-1}, \mathrm{~T}_{6}=$ green manure $17.5 \mathrm{tha}^{-1}$



\begin{tabular}{|c|c|c|c|c|c|c|c|}
\hline \multirow{2}{*}{ Variety } & \multicolumn{7}{|c|}{ Dry matter weight hill $^{-1}(\mathrm{~g})$ at } \\
\hline & $15 \mathrm{DAT}$ & $30 \mathrm{DAT}$ & $45 \mathrm{DAT}$ & $60 \mathrm{DAT}$ & $75 \mathrm{DAT}$ & $90 \mathrm{DAT}$ & Harvest \\
\hline $\mathrm{V}_{1}$ & 3.61 & $15.25 \mathrm{a}$ & $29.30 \mathrm{a}$ & $43.83 \mathrm{~b}$ & $46.50 \mathrm{~b}$ & $45.17 \mathrm{~b}$ & $44.17 \mathrm{~b}$ \\
\hline $\mathrm{V}_{2}$ & 3.53 & $15.78 \mathrm{a}$ & $30.51 \mathrm{a}$ & $51.62 \mathrm{a}$ & $54.40 \mathrm{a}$ & $53.03 \mathrm{a}$ & $52.03 \mathrm{a}$ \\
\hline $\mathrm{V}_{3}$ & 3.15 & $10.95 \mathrm{~b}$ & $23.62 b$ & $35.42 c$ & $38.08 \mathrm{c}$ & $36.75 \mathrm{c}$ & $35.58 \mathrm{c}$ \\
\hline $\operatorname{LSD}_{(0.05)}$ & ns & 2.714 & 3.323 & 3.953 & 4.478 & 3.968 & 3.980 \\
\hline \multicolumn{8}{|c|}{ Fertilizer management } \\
\hline $\mathrm{T}_{1}$ & $5.21 \mathrm{a}$ & $16.17 \mathrm{ab}$ & $33.40 \mathrm{a}$ & $49.44 \mathrm{a}$ & $52.11 \mathrm{a}$ & $50.78 \mathrm{a}$ & $49.78 \mathrm{a}$ \\
\hline $\mathrm{T}_{2}$ & $3.83 \mathrm{~b}$ & $16.52 \mathrm{a}$ & $32.93 \mathrm{a}$ & $50.19 \mathrm{a}$ & $53.08 \mathrm{a}$ & $51.67 \mathrm{a}$ & $50.67 \mathrm{a}$ \\
\hline $\mathrm{T}_{3}$ & $3.05 \mathrm{c}$ & $15.08 \mathrm{bc}$ & $29.02 \mathrm{~b}$ & $44.33 \mathrm{~b}$ & $47.00 \mathrm{~b}$ & $45.67 \mathrm{~b}$ & $44.33 \mathrm{~b}$ \\
\hline $\mathrm{T}_{4}$ & $2.62 \mathrm{~d}$ & $14.62 \mathrm{c}$ & $26.80 \mathrm{~b}$ & $43.00 \mathrm{~b}$ & $45.67 \mathrm{~b}$ & $44.33 \mathrm{bc}$ & $43.33 \mathrm{bc}$ \\
\hline $\mathrm{T}_{5}$ & $3.38 \mathrm{c}$ & $11.09 \mathrm{~d}$ & $22.86 \mathrm{c}$ & $40.39 \mathrm{~b}$ & $43.06 \mathrm{~b}$ & $41.72 \mathrm{c}$ & $40.72 \mathrm{c}$ \\
\hline $\mathrm{T}_{6}$ & $2.14 \mathrm{e}$ & $10.49 \mathrm{~d}$ & $21.84 \mathrm{c}$ & $34.39 c$ & $37.06 \mathrm{c}$ & $35.72 \mathrm{~d}$ & $34.72 \mathrm{~d}$ \\
\hline $\operatorname{LSD}_{(0.05)}$ & 0.356 & 1.239 & 2.698 & 4.206 & 4.005 & 3.602 & 3.418 \\
\hline
\end{tabular}

Figures not sharing the same letters differ significantly at $P \leq 0.05$

$V_{1}$ : Kataribhog, V: Raniselute, $V_{3}$ : BRRI dhan34

$\mathrm{T}_{1}=$ Recommended doses of NPKSZn, $\mathrm{T}_{2}=80 \%$ recommended doses of NPKSZn + green manure $3.5 \mathrm{t} \mathrm{ha}^{-1}, \mathrm{~T}_{3}=60 \%$ recommended doses of NPKSZn + green manure $7 \mathrm{t} \mathrm{ha}^{-1}, \mathrm{~T}_{4}=40 \%$ recommended doses of NPKSZn + green manure $10.5 \mathrm{t} \mathrm{ha}^{-1}, \mathrm{~T}_{5}=20 \%$ recommended doses of NPKSZn + green manure $14 \mathrm{t}$ ha $\mathrm{a}^{-1}, \mathrm{~T}_{6}=$ green manure $17.5 \mathrm{tha}^{-1}$

\section{Yield contributing characters}

Number of effective tillers hill ${ }^{1}$

Significant variation was observed on the number of effective tillers hill ${ }^{-1}$ among the varieties in Aman rice (Table 3). The result showed that highest number of effective tillers hill $^{-1}$ (12.74) was found in BRRI dhan34 followed by Kataribhog (11.86). The lowest number of effective tillers hill $^{-1}$ was obtained in Raniselute (9.04). The result indicated that BRRI dhan34 produced $40.92 \%$ higher effective tillers hill $^{-1}$ than Raniselute. The probable reason for the differences in producing the number of effective tillers hill ${ }^{-1}$ may be the genetic make-up of the variety which is primarily influenced by heredity. These findings collaborate with those reported by Bhowmick and Nayak (2000); Roy et al. (2014); Shiyam et al. (2014) who stated that number of effective tillers hill ${ }^{-1}$ was varied with variety.

The number of effective tillers hill ${ }^{-1}$ was significantly affected due to different fertilizer management (Table 3). The highest number of effective tillers hill ${ }^{-1}$ (13.39) was obtained due to the application of $80 \%$ recommended doses of NPKSZn + green manure $3.5 \mathrm{t} \mathrm{ha}^{-1}$ which was statistically similar with recommended doses of NPKSZn. The lowest number of effective tillers (8.83) hill' ${ }^{-1}$ was obtained in green manure $17.5 \mathrm{t} \mathrm{ha}^{-1}$ which was statistically similar with $20 \%$ recommended doses of NPKSZn + green manure $14 \mathrm{t} \mathrm{ha}^{-1}$. Variations in the number of effective tillers among the organic and inorganic sources were mainly due to their variations in the availability of necessary nutrients. Adequacy of nutrients probably favoured the cellular activities during panicle formation and development that led to increased number of effective tillers hill ${ }^{-1}$. Gosh $e t$ al. (1991); Manzoor et al. (2006); Kandil et al. (2010) also agreed with this view.

\section{Panicle length}

Significant variation was observed on panicle length among the varieties in aman rice (Table 3). Results showed that the maximum panicle length $(27.93 \mathrm{~cm})$ was found in 
Table 3. Effect of varietal variation and fertilizer management on yield contributing characters of rice

\begin{tabular}{|c|c|c|c|c|}
\hline Variety & Number of effective tillers hill ${ }^{-1}$ & Panicle length $(\mathrm{cm})$ & $\begin{array}{l}\text { Number of filled } \\
\text { grains panicle }{ }^{-1}\end{array}$ & 1000-grain weight $(\mathrm{g})$ \\
\hline $\mathrm{V}_{1}$ & $11.86 \mathrm{a}$ & $26.24 \mathrm{~b}$ & $144.4 \mathrm{~b}$ & $11.66 \mathrm{~b}$ \\
\hline $\mathrm{V}_{2}$ & $9.04 \mathrm{~b}$ & $25.62 \mathrm{c}$ & $76.11 \mathrm{c}$ & $11.43 \mathrm{~b}$ \\
\hline $\mathrm{V}_{3}$ & $12.74 \mathrm{a}$ & $27.93 a$ & $192.5 \mathrm{a}$ & $17.22 \mathrm{a}$ \\
\hline $\operatorname{LSD}_{(0.05)}$ & 1.234 & 0.137 & 11.84 & 0.793 \\
\hline \multicolumn{5}{|c|}{ Fertilizer management } \\
\hline $\mathrm{T}_{1}$ & $12.94 \mathrm{a}$ & $26.52 \mathrm{c}$ & $150.5 \mathrm{ab}$ & $14.22 \mathrm{ab}$ \\
\hline $\mathrm{T}_{2}$ & $13.39 \mathrm{a}$ & $27.38 \mathrm{a}$ & $161.7 \mathrm{a}$ & $14.30 \mathrm{a}$ \\
\hline $\mathrm{T}_{3}$ & $11.48 \mathrm{~b}$ & $26.99 \mathrm{~b}$ & $140.5 \mathrm{bc}$ & $13.29 \mathrm{bc}$ \\
\hline $\mathrm{T}_{4}$ & $10.98 \mathrm{~b}$ & $26.30 \mathrm{~d}$ & $136.6 \mathrm{~cd}$ & $13.46 \mathrm{a}-\mathrm{c}$ \\
\hline $\mathrm{T}_{5}$ & $9.64 \mathrm{c}$ & $26.58 \mathrm{c}$ & $126.6 \mathrm{~d}$ & $13.05 \mathrm{~cd}$ \\
\hline $\mathrm{T}_{6}$ & $8.83 \mathrm{c}$ & $25.79 \mathrm{e}$ & $110.1 \mathrm{e}$ & $12.30 \mathrm{~d}$ \\
\hline $\operatorname{LSD}_{(0.05)}$ & 0.918 & 0.195 & 12.32 & 0.949 \\
\hline
\end{tabular}

Figures not sharing the same letters differ significantly at $P \leq 0.05$

$V_{1}$ : Kataribhog, V2: Raniselute, $V_{3}$ : BRRI dhan34

$\mathrm{T}_{1}=$ Recommended doses of NPKSZn, $\mathrm{T}_{2}=80 \%$ recommended doses of NPKSZn + green manure $3.5 \mathrm{t} \mathrm{ha}^{-1}, \mathrm{~T}_{3}=60 \%$ recommended doses of NPKSZn + green manure $7 \mathrm{t} \mathrm{ha}^{-1}, \mathrm{~T}_{4}=40 \%$ recommended doses of NPKSZn + green manure $10.5 \mathrm{tha}^{-1}, \mathrm{~T}_{5}=20 \%$ recommended doses of NPKSZn + green manure $14 \mathrm{t}$ ha $\mathrm{a}^{-1}, \mathrm{~T}_{6}=$ green manure $17.5 \mathrm{tha}^{-1}$

BRRI dhan 34 and the minimum $(25.62 \mathrm{~cm})$ was obtained in Raniselute. The variation as assessed might be due to genetic characters of the varieties primarily influenced by the heredity. Sarker et al. (2013) and Hossain et al. (2014) also reported that panicle length varied among varieties.

Panicle length was significantly affected due to different fertilizer management (Table 3). The maximum panicle length $(27.38 \mathrm{~cm})$ was obtained due to the application of $80 \%$ recommended doses of NPKSZn + green manure $3.5 \mathrm{t}$ $\mathrm{ha}^{-1}$ which was statistically different from others. The minimum panicle length $(25.79 \mathrm{~cm})$ was obtained in green manure $17.5 \mathrm{tha}^{-1} .80 \%$ recommended doses of NPKSZn + green manure $3.5 \mathrm{t} \mathrm{ha}^{-1}$ took part in panicle formation as well as elongation and for this panicle length increased. Islam et al. (2008); Kandil et al. (2010); Mannan et al. (2010) reported similar results.

\section{Number of filled grain panicle-1}

Variety differed significantly in the production of the number of filled grains panicle-1 (Table 3). The highest number of filled grains panicle ${ }^{-1}$ (192.50) was observed in BRRI dhan34, and the lowest number of filled grains panicle $^{-1}$ (76.11) was obtained in Raniselute. The result showed that BRRI dhan34 produced $152.92 \%$ higher filled grains panicle ${ }^{-1}$ than Raniselute. Varietal variation regarding the number of filled grains panicle ${ }^{-1}$ might be due to their variation in genetic constitutions and also due to variation in photosynthetic assimilate accumulation especially after heading. Sarker et al. (2013); Hossain et al. (2014); Shiyam et al. (2014) reported the variable number of filled grains panicle .

Different fertilizer management showed significant variation on production of filled grains panicle ${ }^{-1}$ (Table 3). The highest number of filled grains panicle ${ }^{-1}(161.70)$ was obtained by the application of $80 \%$ recommended doses of NPKSZn + green manure $3.5 \mathrm{t} \mathrm{ha}^{-1}$ which is statistically similar with recommended doses of NPKSZn whereas the lowest (110.10) was obtained from green manure $17.5 \mathrm{t} \mathrm{ha}^{-1}$. $80 \%$ recommended doses of NPKSZn + green manure $3.5 \mathrm{t}$ ha $^{-1}$ produced $46.87 \%$ higher number of filled grains panicle ${ }^{1}$ than green manure $17.5 \mathrm{t} \mathrm{ha}^{-1}$. An adequate supply of nutrients contributed to grain formation, which probably increased the number of grains panicle ${ }^{-1}$.

\section{0-grain weight}

Variety had significant effect on the weight of 1,000grains. The highest 1,000 grain weight $(17.22 \mathrm{~g})$ was observed in BRRI dhan34 and the lowest weight (11.43 g) was observed in Raniselute (Table 3). The result showed that BRRI dhan 34 produced $50.65 \%$ heavier seed than Raniselute. The variation in 1,000-grain weight might be due to differences in length and breadth of the grains that were partly controlled by the genetic makeup of the variety under study. Chowdhury and Ghosh (1978) stated that 1,000 -grain weight highly varied due to variety ranged from $9.00 \mathrm{~g}$ to $23.00 \mathrm{~g}$ fine and scented rice varieties. The results agreed with the findings of Sarker $e t$ al. (2013); Shiyam $e t$ al. (2014)

The weight of 1,000-grain was significantly influenced by the different levels of fertilizer (Table 3 ). The highest weight $(14.30 \mathrm{~g})$ of 1,000-grains was recorded due to the application of $80 \%$ recommended doses of NPKSZn + green manure $3.5 \mathrm{t}$ ha $^{-1}$ which was followed by recommended doses of NPKSZn (14.22 g) and 40\% recommended doses of NPKSZn + green manure $10.5 \mathrm{tha}^{-1}$ $(13.46 \mathrm{~g})$. The lowest weight $(12.30 \mathrm{~g})$ of 1000 -grain was recorded from the green manure $17.5 \mathrm{t} \mathrm{ha}^{-1}$. The results agreed with the findings of Manzoor et al. (2006); Mannan et al. (2010).

\section{Yield and harvest index}

Varieties differed significantly in producing grain, straw, biological yield and harvest index of aromatic Aman rice (Table 4). Among the varieties, BRRI dhan34 showed its superiority in producing highest grain yield $\left(2.26 \mathrm{t} \mathrm{ha}^{-1}\right)$ and harvest index (29.99\%) while the inferiority in producing lowest straw yield $\left(5.31 \mathrm{t} \mathrm{ha}^{-1}\right)$ and biological yield (7.57 $\left.\mathrm{t} \mathrm{ha} \mathrm{a}^{-1}\right)$. Maximum straw yield $\left(7.81 \mathrm{t} \mathrm{ha}^{-1}\right)$ and biological yield $\left(9.05 \mathrm{t} \mathrm{ha}^{-1}\right)$ with minimum grain yield $\left(1.24 \mathrm{t} \mathrm{ha} \mathrm{a}^{-1}\right)$ and harvest index $(13.56 \%)$ were obtained from the variety Raniselute. The yield of rice mainly depends on the yield contributing characters like the number of effective tillers 
216

hill $^{-1}$, length of panicle, number of filled grains panicle ${ }^{-1}$ and 1,000-grain weight. Improvement of yield components increased the yield of grains agreed with the findings of Manzoor et al. (2006); Islam et al. (2008); Kandil et al. (2010); Mannan et al. (2010). Physiological parameters also play an important role in rice yield, which was supported by Cui-Jing et al. (2000). They obtained that higher rice yield possible by increasing total dry matter and harvest index. Grain yield differences due to varieties were also reported by Biswas et al. (1998). The results agreed with the findings of Sarker et al. (2013); Hossain et al. (2014); Shiyam et al. (2014). The differences in straw yield among the varieties might be attributed to the genetic makeup of the varieties. Several researchers also obtained variable straw yield among the varieties (Chowdhury et al., 1993; Kumar et al., 1995; Patel, 2000). Sokoto and Muhammad (2014) also found the similar results in case of harvest index due to varietal variations.

The significant difference was observed for grain, straw, biological yield and exerted non-significant variation on harvest index due to different levels of fertilizer (Table 4). The maximum grain yield $\left(2.17 \mathrm{t} \mathrm{ha}^{-1}\right)$, straw yield $\left(7.64 \mathrm{t} \mathrm{ha}^{-1}\right)$, biological yield $\left(9.80 \mathrm{t} \mathrm{ha}^{-1}\right)$ was obtained due to the application of $80 \%$ recommended doses of NPKSZn + green manure $3.5 \mathrm{t} \mathrm{ha}^{-1}$ which did not differ significantly with recommended doses of NPKSZn. The minimum grain yield $\left(1.53 \mathrm{t} \mathrm{ha}^{-1}\right)$, straw yield $(6.00 \mathrm{t}$ $\mathrm{ha}^{-1}$ ) and biological yield $\left(7.53 \mathrm{t} \mathrm{ha}^{-1}\right)$ were found from green manure $17.5 \mathrm{t} \mathrm{ha}{ }^{-1}$. Results revealed that a combination of organic and inorganic fertilizer sources resulted in comparable better rice yields. It might be due to the presence of organic manure that increased the availability of nutrients in soil as a result of the mineralization of manures leading to the increased uptake by rice plants. Also the organic acids produced during decomposition solubilise the $\mathrm{P}$ and micronutrients present in the soil. The increase in yield might be due to the contribution of more number of effective tillers hill ${ }^{-1}$, panicle length, number of filled grains panicle ${ }^{-1}$ and 1,000grain weight.

\section{Proximate composition of rice grain}

Moisture content invariably affects the quality and palatability of rice grains (Oko and Onyekwere, 2010), which plays a significant role in determining the shelf life (Webb, 1985). Ash content plays an important role to reflect the mineral elements of a food sample (Bhat and Sridhar, 2008; Mbatchou and Dawda, 2013) and gives an idea to determine the levels of essential minerals present in the food (Edeogu et al., 2007). Fat in rice is a good source of linoleic and other essential fatty acids but does not contain cholesterol (Eggum et al., 1982). Fat content influences the taste of cooked rice because rice with high-fat content tends to be tastier and have less starch (Hirokadzu et al., 1979). Protein in rice is essential as proteins to form the basic building blocks for cells and tissue repairs in the body (Mbatchou and Dawda, 2013). Protein content influences the nutritional quality of rice (Sompong et al., 2011). Rice protein content comprises up to $8 \%$ of the grain (Juliano, 1985), which is low but of high nutritional value (FAO, 1970; Chaudhary and Tran, 2001). Nevertheless, much research mentioned protein content up to $15 \%$ in different rice varieties (Sotelo et al., 1990; Kennedy and Burlingame, 2003). Resurrection et al. (1979) classified protein content more than $10 \%$ as high content. Rice is the starchy staple food and a major source of carbohydrates. In present study ash, fat, protein, and carbohydrate content showed significant variation and the non-significant result was found on moisture content in rice grain due to varietal variations (Table 5). The highest protein content $(8.85 \%)$, lowest fat content $(2.71 \%)$ was recorded from variety Kataribhog. Raniselute variety gave the highest ash, fat content $(1.59,2.81 \%$, respectively) and lowest carbohydrate content $(77.12 \%)$. Highest carbohydrate content (77.63\%), lowest ash and protein content (1.40, 8.52\%, respectively) was obtained from the rice grain of BRRI dhan34. The difference in moisture content among the rice accessions might be due to the variation in moisture content in paddy after harvesting (Asaduzzaman et al., 2013). The differences of ash content in all aromatic and non-aromatic rice accessions may occur due to the differences in the mineral

Table 4. Effect of varietal variation and fertilizer management on yield and harvest index of rice

\begin{tabular}{|c|c|c|c|c|}
\hline Variety & Grain yield $\left(\mathrm{t} \mathrm{ha}^{-1}\right)$ & Straw yield $\left(\mathrm{t} \mathrm{ha}^{-1}\right)$ & Biological yield $\left(\mathrm{t} \mathrm{ha}^{-1}\right)$ & Harvest index (\%) \\
\hline $\mathrm{V}_{1}$ & $1.96 \mathrm{~b}$ & $7.02 \mathrm{~b}$ & $8.98 \mathrm{a}$ & $21.91 \mathrm{~b}$ \\
\hline $\mathrm{V}_{2}$ & $1.24 \mathrm{c}$ & $7.81 \mathrm{a}$ & $9.05 \mathrm{a}$ & $13.56 \mathrm{c}$ \\
\hline $\mathrm{V}_{3}$ & $2.26 \mathrm{a}$ & $5.31 \mathrm{c}$ & $7.57 \mathrm{~b}$ & $29.99 a$ \\
\hline $\operatorname{LSD}_{(0.05)}$ & 0.168 & 0.474 & 0.633 & 0.598 \\
\hline \multicolumn{5}{|c|}{ Fertilizer management } \\
\hline $\mathrm{T}_{1}$ & $2.04 \mathrm{ab}$ & $7.25 \mathrm{ab}$ & $9.29 \mathrm{ab}$ & 22.35 \\
\hline $\mathrm{T}_{2}$ & $2.17 \mathrm{a}$ & $7.64 \mathrm{a}$ & $9.80 \mathrm{a}$ & 22.38 \\
\hline $\mathrm{T}_{3}$ & $1.90 \mathrm{~b}$ & $6.80 \mathrm{bc}$ & $8.70 \mathrm{~b}$ & 22.52 \\
\hline $\mathrm{T}_{4}$ & $1.69 \mathrm{c}$ & $6.37 \mathrm{~cd}$ & $8.06 \mathrm{c}$ & 21.53 \\
\hline $\mathrm{T}_{5}$ & $1.60 \mathrm{c}$ & $6.22 \mathrm{~cd}$ & $7.82 \mathrm{c}$ & 20.94 \\
\hline $\mathrm{T}_{6}$ & $1.53 \mathrm{c}$ & $6.00 \mathrm{~d}$ & $7.53 \mathrm{c}$ & 21.18 \\
\hline $\operatorname{LSD}_{(0.05)}$ & 0.161 & 0.622 & 0.614 & ns \\
\hline
\end{tabular}

Figures not sharing the same letters differ significantly at $P \leq 0.05$

$V_{1}$ : Kataribhog, V: Raniselute, V3: BRRI dhan34

$\mathrm{T}_{1}=$ Recommended doses of NPKSZn, $\mathrm{T}_{2}=80 \%$ recommended doses of NPKSZn + green manure $3.5 \mathrm{t} \mathrm{ha}^{-1}, \mathrm{~T}_{3}=60 \%$ recommended doses of NPKSZn + green manure $7 \mathrm{t} \mathrm{ha}^{-1}, \mathrm{~T}_{4}=40 \%$ recommended doses of NPKSZn + green manure $10.5 \mathrm{tha}^{-1}, \mathrm{~T}_{5}=20 \%$ recommended doses of NPKSZn + green manure $14 \mathrm{t}$ ha ${ }^{-1}, \mathrm{~T}_{6}=$ green manure $17.5 \mathrm{tha}^{-1}$ 
Table 5. Effect of varietal variation and fertilizer management on proximate composition of rice

\begin{tabular}{cccccc}
\hline Variety & Moisture content (\%) & Ash content $(\%)$ & Fat content (\%) & Protein content (\%) & Carbohydrate content (\%) \\
\hline $\mathrm{V}_{1}$ & 9.74 & $1.49 \mathrm{ab}$ & $2.71 \mathrm{~b}$ & $8.85 \mathrm{a}$ & $77.21 \mathrm{~b}$ \\
$\mathrm{~V}_{2}$ & 9.78 & $1.59 \mathrm{a}$ & $2.81 \mathrm{a}$ & $8.70 \mathrm{~b}$ & $77.12 \mathrm{~b}$ \\
$\mathrm{~V}_{3}$ & 9.72 & $1.40 \mathrm{~b}$ & $2.73 \mathrm{~b}$ & $8.52 \mathrm{c}$ & $77.63 \mathrm{a}$ \\
\hline $\mathrm{LSD}(0.05)$ & $\mathrm{ns}$ & 0.117 & 0.051 & 0.106 & 0.319 \\
Fertilizer management & & & & \\
$\mathrm{T}_{1}$ & $8.75 \mathrm{~d}$ & $1.29 \mathrm{~d}$ & $2.60 \mathrm{c}$ & $8.81 \mathrm{a}$ & $78.56 \mathrm{a}$ \\
$\mathrm{T}_{2}$ & $9.61 \mathrm{c}$ & $1.57 \mathrm{~b}$ & $2.81 \mathrm{~b}$ & $8.85 \mathrm{a}$ & $77.17 \mathrm{bc}$ \\
$\mathrm{T}_{3}$ & $10.16 \mathrm{ab}$ & $1.48 \mathrm{c}$ & $3.07 \mathrm{a}$ & $8.77 \mathrm{a}$ & $76.53 \mathrm{c}$ \\
$\mathrm{T}_{4}$ & $10.43 \mathrm{a}$ & $1.51 \mathrm{bc}$ & $2.62 \mathrm{c}$ & $8.40 \mathrm{~b}$ & $77.04 \mathrm{bc}$ \\
$\mathrm{T}_{5}$ & $10.11 \mathrm{~b}$ & $1.34 \mathrm{~d}$ & $2.89 \mathrm{~b}$ & $8.26 \mathrm{~b}$ & $77.40 \mathrm{~b}$ \\
$\mathrm{~T}_{6}$ & $9.42 \mathrm{c}$ & $1.79 \mathrm{a}$ & $2.51 \mathrm{c}$ & $9.06 \mathrm{a}$ & $77.21 \mathrm{bc}$ \\
$\mathrm{LSD}_{(0.05)}$ & 0.295 & 0.075 & 0.118 & 0.297 & 0.794 \\
\hline
\end{tabular}

Figures not sharing the same letters differ significantly at $P \leq 0.05$

$\mathrm{V}_{1}$ : Kataribhog, $\mathrm{V}_{2}$ : Raniselute, $\mathrm{V}_{3}$ : BRRI dhan 34

$\mathrm{T}_{1}=$ Recommended doses of NPKSZn, $\mathrm{T}_{2}=80 \%$ recommended doses of NPKSZn + green manure $3.5 \mathrm{t} \mathrm{ha}^{-1}, \mathrm{~T}_{3}=60 \%$ recommended doses of NPKSZn + green manure $7 \mathrm{t} \mathrm{ha}^{-1}, \mathrm{~T}_{4}=40 \%$ recommended doses of NPKSZn + green manure $10.5 \mathrm{t} \mathrm{ha}^{-1}, \mathrm{~T}_{5}=20 \%$ recommended doses of NPKSZn + green manure $14 \mathrm{t}$ ha ${ }^{-1}, \mathrm{~T}_{6}=$ green manure $17.5 \mathrm{tha}^{-1}$

content of the soils and the water used for irrigation (Shayo et al., 2006). The differences in fat content among the aromatic and non-aromatic rice accessions could be accounted for by the differences in the degree of milling since most of the fat in rice is concentrated in the aleurone layer of the kernel (Wang et al., 2006). The variations in fat value in rice accessions may be due to oxidation of fat because most of the fat in rice grains is unsaturated which undergoes oxidation easily by atmospheric oxygen (Hirokadzu et al., 1979). The variations of protein content in different rice accessions might be due to several factors such as water supply, handling, application of fertilizer (soil nitrogen availability), environmental stress (such as salinity and alkalinity, temperatures and diseases), location of growing areas, growing conditions and time which tend to increase the grain protein content (Buresova et al., 2010). The high percentage carbohydrate contents of the rice varieties showed that rice is a good source of energy. This low carbohydrate content may be attributed to its high moisture content which also affects the milling quality and other environmental factors. The variation of the carbohydrate content of different rice accessions has also been reported by Oko and Ugwu (2011); Saikia et al. (2012); Thomas et al. (2013); Rohman et al. (2014), but neither higher nor within the range of reported values of Shayo et al. (2006); Subudhi et al. (2013).

Significant variation was observed on proximate composition of rice grain due to different levels of fertilizer (Table 5). The highest ash and protein, moisture, fat, carbohydrate content $(1.79,9.06,10.43,3.07,78.56 \%$, respectively) was observed in green manure $17.5 \mathrm{t} \mathrm{ha}^{-1}, 40$ and $60 \%$ recommended doses of NPKSZn + green manure 7 and $10.5 \mathrm{t} \mathrm{ha}^{-1}$, recommended doses of NPKSZn, respectively. The lowest moisture, ash, fat, protein and carbohydrate content $(8.75,1.29,2.51,8.26,76.53 \%$, respectively) was observed at Recommended doses of NPKSZn, green manure $17.5 \mathrm{t} \mathrm{ha}{ }^{-1}, 20$ and $60 \%$ recommended doses of NPKSZn + green manure 7 and 14 tha $a^{-1}$, respectively.

\section{Conclusions}

Reviewing the results of the present study, it might be concluded that BRRI dhan 34 and $80 \%$ recommended doses of NPKSZn + green manure $3.5 \mathrm{t} \mathrm{ha}^{-1}$ showed the best results compared to other treatments.

\section{Acknowledgements}

The authors acknowledge the funding of this study from the Ministry of Science and Technology-Government of the People's Republic of Bangladesh.

\section{References}

Anjum FM, Pasha I, Bugti MA, Batt MS (2007). Mineral composition of different rice varieties and their milling fractions. Pakistan Journal of Agricultural Science 44(2):51-58.

AOAC (1975). Official Methods of Analysis. Association of official Analytical Chemist (12thedn), AOAC, Washington, DC, USA.

AOAC (1990). Official Methods of Analysis. Association of official Analytical Chemist (15th edn), AOAC, Washington, DC, USA.

Asaduzzaman M, Haque ME, Rahman J, Hasan SMK, Ali MA, Akter MS, Ahmed M (2013). Comparisons of physiochemical, total phenol, flavonoid content and functional properties in six cultivars of aromatic rice in Bangladesh. African Journal of Food Science 7(8):198-203.

Bair W (1990). Characterization of the environment for sustainable agriculture in Semi-arid Tropics. In: Proc. Sustainable Agriculture Issue, Prospective and Prospects in Semi-arid Tropics (ed. Singh RP), Hydderabad, India. India Society of Agronomy pp 90-128.

BBS (Bangladesh Bureau of Statistics) (2013). Monthly Statistics Bulletin, Bangladesh pp 71 .

BBS (Bangladesh Bureau of Statistics) (2003). Statistical pocket book of Bangladesh. Dhaka, Bangladesh.

Bergman CJ, Delgado JT, Bryant R, Grimm C, Cadwallader KR, Webb BD (2000). Rapid gas chromatographic technique for quantifying 2acetyl-1-pyrroline and hexanal in rice (Oryza sativa L.). Cereal Chemistry $77(4): 454458$. 
218

Bhat R, Sridhar KR (2008). Nutritional quality evaluation of electron beamirradirated lotus (Nelumbo nucifera) seeds. Food Chemistry 107(1):174 184.

Bhattacharjee P, Singhal RS, Kulkarni PR (2002). Basmati rice: A review. International Journal of Food Science and Technology 37:1-12.

Bhowmick N, Nayak RL (2000). Response of hybrid rice (Oryza sativa) varieties to nitrogen, phosphorus and potassium fertilizers during dry (aman) season in West Bengal. Indian Journal of Agronomy 45(2):323326.

Bhuiyan NI, Zaman SK (1996). Use of green manuring crops in rice fields for sustainable production in Bangladesh agriculture. In: Rahman M, Podder AK, Van Hove C, Begum ZNT, Heulin T, Hartmann A (Eds). Biological nitrogen fixation associated with rice production. Developments in Plant and Soil Sciences 70:51-64.

Bisne R, Motiramani NK, Sarawgi AK (2006). Identification of high yielding hybrids in rice. Bangladesh Journal of Agricultural Research 31(1):171-174.

Bisne R, Sarawgi AK (2008). Agro-morphological and quality characterization of Badshah bhog group from aromatic rice germplasm of Chhattisgarh. Bangladesh Journal of Agricultural Research 33(3):479-492.

Biswas JW, Hossain MA, Sarker BC, Hansan M, Haque MZ (1998). Yield performance of several rice varieties seeded directly as late aman crops. Bangladesh Journal of Life Sciences 10(1):47-52.

Buresova I, Sedlackova I, Famera O, Liparsky J (2010). Effect of growing conditions on starch and protein content in triticale grain and amylase content in starch. Plant, Soil and Environment 56(3):99-104.

Chaudhary RC, Tran DV (2001). Specialty rices of the world: A prologue. In: Chaudhary RC, Tran DV. Specialty Rice of the World: Breeding Production, and Marketing Rome, Italy: FAO, and New Delhi, India: Oxford\&IBH PublishingCo.Pvt.Ltd.pp3-14.

Chen Y, Wang M, Ouwerkerk PB (2012). Molecular and environmental factors determining grain quality in rice. Food and Energy Security 1(2):111-132.

Chowdhury D, Ghosh AK (1978). Evaluation of agronomic and physiological characters of fine and scented rice varieties. Indian Journal of Agricultural Science 48(10):373-37.

Chowdhury MJU,Sarkar AU, Sarkar MAR, Kashem MA (1993). Effect of variety and number of seedlings hill-1 on the yield and its components on late transplanted aman rice. Bangladesh Journal of Agricultural Science 20(2):311-316.

Cui-jing, Kusutani A, Toyata M, Asunuma K, Cui J (2000). Studies on the varietals differences of harvest index and morphological characteristics of rice.Japanese Journal ofCrop Science 69(3):359-364.

Dela Cruz N, Khush GS (2000). Rice grain quality evaluation procedures. Singh RK, Singh US, Khush GS. (Eds.), Aromatic Rices, Oxford \& IBHPublishing Co. Pvt. Ltd,New Delhi, Indiapp 16-28.

Edeogu CO, Ezeonu FC, Okaka ANC, Ekuma CE, Elom SO (2007). Proximate composition of staple food crops in Ebonyi State (South Eastern Nigeria). International Journal of Biotechnology and Biochemistry 3(1):1-8.

Eggum BO, Juliano BO, Magnificat CC (1982). Protein and energy utilization of rice milling fractions. Plant Foods for Human Nutrition 31(4):371-376.
Fageria NK (2007) Green manuring in crop production. Journal of Plant Nutrition 30(5):691-719.

FAO (Food and Agriculture Organization) (1970). Amino acid content of foods and biological data on proteins. Rome nutrition division: $\mathrm{FAO}, \mathrm{pp}$ 122.

Fitzgerald MA, McCouch SR, Hall RD (2009). Not just a grain of rice: The quest for quality. Trendsin PlantScience 14:133-139.

Gardner FP, Pearce RB, Mistechell RL (1985). Physiology of crop plants. Iowa State University Press, Iowapp 66.

Ghosh BC, Raghavaian CV, Jana MK (1991). Effect of seed rate and nitrogen on growth and yield of direct sown rice (Oryza sativa $\mathrm{L}$.) under intermediate deep water condition. Indian Journal of Agronomy 36:227-228.

Gomez KA, Gomez AA (1984). Statistical Procedure for Agricultural Research. 2nded.John Wiley and Sons. New York pp 64.

Hirokadzu T, Harue T, Keishi F (1979). Influence of cropping season on lipid content and fatty acid composition of lowland non-glutinous brown rice.Japanese Journal ofCropScience 48(3):371-377.

Hossain MM, Sultana F, Rahman AHMA (2014). A comparative screening of hybrid, modern varieties and local rice cultivar for brown leat spot disease susceptibility and yield performance. Archives of Phytopathology and Plant Protection 47(7):795-802

Hossain M, Singh VP (2000). Fertilizer Use in Asian Agriculture: Implications for sustaining food security and the environment. Nutrient Cydingin Agroecosystems 57(2):155-169.

Islam MR, Akther M, Afroz H, Bilkis S (2013). Effect of nitrogen from organic and inorganic sources on the yield and nitrogen use efficiency of BRRI dhan28. Bangladesh Journal of Progressive Science and Technology 11(2):179-184

Islam MS, Akhter MM, Rahman MS, Banu MB, Khalequzzaman KM (2008). Effect of nitrogen and number of seedlings per hill on the yield and yield components of T. aman rice (BRRI dhan33). International Journal of Sustainable Crop Production 3(3):61-65.

Juliano BO (1985). Factors affecting nutritional properties of rice protein. Transactions National Academy of Science and Technology 7:205-216.

Kandil AA, El-Kalla SE, Badawi AT, El-Shayb OM (2010). Effect of hill spacing, nitrogen levels and harvest date on rice productivity and grain quality. Crop and Environment 1(1):22-26.

Kennedy G, Burlingame B (2003). Analysis of food composition data on rice from agenetic resource perspective. Food Chemistry 80(4):589-596.

Kohayashi Y, Abe S, Matamoto K (1989). Growth and yield of paddy rice under natural cultivation. Soil and Fertilizer 54(12):19-31.

Kumar GH, Reddy SN, Ikramullah M (1995). Effect of age of seedling and nitrogen levels on the performance of rice (Oryza saliva) under late planting Indian Journal of Agricultural Science 65(5):354355.

Laohakunjit N, Kerdchoechuen O (2007). Aroma enrichment and the change during storage of none-aromatic milled rice coated with extracted natural flavor. Food Chemistry 101(1):339-344

Mahmud AJ, Shamsuddoha ATM, Haque MN (2016). Effect of organic and inorganic fertilizer on the growth and yield of rice (Oryza sativa $\mathrm{L})$. NatureScience 14(2):45-54

Mannan MA, Bhuiya MSU, Hossain SMA, Akhand MIM (2010). Nitrogen on yield and other plant characters of local T. aman rice, var. 
optimization of nitrogen rate for aromatic basmati rice (Oriza sativa L.) Bangladesh Journal of Agricultural Research 35(1):157-165.

Manzoor Z, Awan TH, Zahid MA, Faiz FA (2006). Response of rice crop (super basmati) to different nitrogen levels. Journal of Animal and Plant Science 16(1-2):52-55.

Mbatchou VC, Dawda S (2013). The nutritional composition of four rice varieties grown and used in different food preparations in KassenaNankana district, Ghana. International Journal of Research in Chemistry and Environment 3(1):308-315.

Oko AO, Onyekwere SC (2010). Studies on the proximate chemical composition and mineral element contents of five new lowland rice varieties in Ebonyi State. International Journal of Biotechnology and Biochemistry 6(6):949-955.

Oko AO, UgwuSI (2011). The proximate and mineral compositions of five major rice varieties in Abakaliki, South-Eastern Nigeria. African Journal of Biotechnology 6(8):1016-1020.

Patel JR (2000). Effect of water regime, variety blue green algae on rice (Oryza sativa) hybrids. Indian Journal of Agronomy 45(1):103-106.

Rekabdar MFH (2004). Dhan Chasher Nana Katha. Krishikatha 67(2):3940.

Resurrection AP, Juliano BO, Tanaka Y (1979). Nutritional content and distribution in milling fractions of rice grains. Journal of the Science of Food and Agriculture 30(5):475-481.

Rohman A, Helmiyati S, Hapsari M, Larasati Setyaningrum D (2014). Rice in health and nutrition. International Food Research Journal 21(1):1324.

Roy SK, Ali MY, Jahan MS, Saha UK, Ahmad-Hamdani MS, Hasan MM, Alam MA (2014). Evaluation of growth and yield attributing characteristics of indigenous Boro rice varieties. Life Science Journal 11(4):122-126.

Saikia S, Dutta H, Saikia D, Mahanta CL (2012). Quality characterization and estimation of phytochemical content capacity of aromatic pigmented and non-pigmented rice varieties. Food Research International 46(1):334-340.

Sarker BC, Zahan M, Majumder UK, Islam MA, Roy B (2013). Growth and yield potential of some local and high yielding Boro rice cultivars. Journal of Agronomy and Environment 7(1):107-110.
Shayo NB, Mamiro P, Nyaruhucha CNM, Mamboleo T (2006). Physicochemical and grain cooking characteristics of selected rice cultivars grown in Morogoro. Tanzania Journal ofScience 32(1):29-36.

Shiyam JO, Binang WB, Ittah, MA (2014). Evaluation of growth and yield attributes of some lowland Chinese hybrid rice (Oryza sativa L.) varieties in the Coastal Humid Forest Zone of Nigeria. IOSR Journal of Agriculture and Veterinary Science 7(2):70-73.

Sokoto MB, Muhammad A (2014). Response of rice varieties to water stress in Sokoto, Sudan Savannah, Nigeria. Journal of Biosciences and Medicines 2:68-74.

Sompong R, Siebenhandl-Ehn S, Linsberger-Martin G, Berghofer E (2011). Physicochemical and antioxidant properties of red and black rice varieties from Thailand, China and Sri Lanka. Food Chemistry 124(1):132-140.

Sotelo A, Sousa V, Montalvo I, Hernandez M, Hernandez-Arago I (1990). Chemical composition fractions of 12 Mexican varieties of rice obtained duringmilling. Cereal Chemistry 67(2):209-212.

Subudhi H, Meher J, Singh ON, SharmaSG, Das S (2013). Grain and food quality traits in some aromatic long and short grain rice varieties of India. Journal of Food, Agriculture and Environment 11:14341436.

Thomas R, Wan-Nadiah WA, Bhat R (2013). Physiochemical properties, proximate composition, and cooking qualities of locally grown and imported rice varieties marketed in Penang, Malaysia. International Food Research Journal 20(3):1345-1351.

Verma DK, Srivastav PP (2017). Proximate composition, mineral content and fatty acids analyses of aromatic and non-aromatic Indian rice. Rice Science 24(1):21-31.

Wang HL, Wan XY, Bi JC, WangJK, Jiang L, Chen LM, Zhai HQ, Wan JM (2006). Quantitative analysis of fat content in rice by near infrared spectroscopy technique. Cereal Chemistry 83(4):402-406.

Webb BD (1985). Criteria of rice quality in the US. In: Juliano BO. Rice Chemistry and Technology. 2nd ed. St Paul, MI, USA: The American Association of Cereal Chemists pp 403-442.

Yoshihashi T, Nguyen TTH, Kabaki N (2004). Area dependency of 2acetyl-1-pyrroline content in an aromatic rice variety, Khao Dawk Mali 105.Japan Agricultural Research Quarterly 38(2):105-109. 